\title{
Effect of Synchronization Protocols on Follicular Development and Estradiol and Progesterone Concentrations of Dairy Heifers
}

\author{
J. L. Stevenson, ${ }^{\star}$ J. C. Dalton,† J. E. P. Santos,‡ R. Sartori,§ A. Ahmadzadeh,\# and R. C. Chebel, ${ }^{\star 1,2}$ \\ ${ }^{*}$ Caine Veterinary Teaching Center, and \\ †Research and Extension Center, University of Idaho, Moscow 83844 \\ $\ddagger$ School of Veterinary Medicine, University of California-Davis, Tulare 93274 \\ §Embrapa Recursos Genéticos e Biotecnológicos, Brasília, Distrito Federal, Brazil \\ \#Animal and Veterinary Science Department, University of Idaho, Moscow 83844
}

\begin{abstract}
The objectives were to evaluate the effect of synchronization protocols on follicular development and estradiol 17- $\beta\left(\mathrm{E}_{2}\right)$ and progesterone $\left(\mathrm{P}_{4}\right)$ concentrations in dairy heifers. In experiment 1, 36 heifers were assigned to 1 of 6 synchronization protocols in a $3 \times 2$ factorial design: presynchronization with $\mathrm{GnRH}$ on study d -6 or -9 [study d $0=$ initiation of the Cosynch + CIDR (controlled internal drug releasing insert containing $\mathrm{P}_{4}$ ) protocol] or no presynchronization (control) and one injection of $\mathrm{PGF}_{2 \alpha}$ or not on study d 0 . In experiment 2 , 126 heifers were assigned to 1 of 4 synchronization protocols in a $2 \times 2$ factorial arrangement: presynchronization or not with $\mathrm{GnRH}$ on study d -6 and injection of $\mathrm{PGF}_{2 \alpha}$ or not on study $\mathrm{d} 0$. In experiments 1 and 2, all heifers received a modified Cosynch protocol with CIDR for $7 \mathrm{~d}$ starting on study $\mathrm{d} 0$. After the $\mathrm{PGF}_{2 \alpha}$ of the Cosynch and removal of the CIDR, heifers were detected in estrus and inseminated. Those not inseminated by study d 10 received an injection of $\mathrm{GnRH}$ and were timed-inseminated. Ovaries were scanned by ultrasound on d 0,2 , and 5, daily from d 7 to 14 , and on d 16. Blood samples collected on d 0, 2, 7, 9, and 16 were analyzed for $\mathrm{P}_{4}$, and the blood sample collected on $\mathrm{d} 9$ was analyzed for $\mathrm{E}_{2}$. Pregnancy was diagnosed at 28 and $40 \pm 3 \mathrm{~d}$ after artificial insemination. In experiment 1 , there was a tendency for the presynchronization protocol to affect the proportion of heifers ovulating in response to the first GnRH injection of the Cosynch + CIDR protocol. In experiment 2, a greater proportion of presynchronized heifers ovulated in response to the first GnRH injection. Although heifers receiving $\mathrm{PGF}_{2 \alpha}$ had larger ovulatory follicles on $\mathrm{d} 7$ and before ovulation and shorter intervals to estrus and ovulation, these
\end{abstract}

Received August 17, 2007.

Accepted December 28, 2007.

${ }^{1}$ Corresponding author: rchebel@vmtrc.ucdavis.edu

${ }^{2}$ Present address: Veterinary Medicine Extension, University of California-Davis, Tulare 93274. heifers tended to have decreased concentrations of $\mathrm{E}_{2}$ during proestrus. Presynchronization of dairy heifers with $\mathrm{GnRH}$ increased ovulation in response to the first GnRH injection, and treatment of heifers with $\mathrm{PGF}_{2 \alpha}$ at initiation of the Cosynch + CIDR protocol increased the size of the ovulatory follicle and reduced the intervals to estrus and ovulation.

Key words: heifer, ovulation synchronization, follicle growth

\section{INTRODUCTION}

Although the use of ovulation synchronization protocols and fixed-time AI has resulted in acceptable conception rates in lactating dairy cows (Pursley et al., 1997; Moreira et al., 2001; Cerri et al., 2004), dairy heifers inseminated at a fixed time after the Ovsynch protocol have reduced conception rates as compared with heifers inseminated on detection of estrus (Schmitt et al., 1996; Pursley et al., 1997; Tenhagen et al., 2005). The pattern of follicular development of dairy heifers is different from that of lactating dairy cows (Sartori et al., 2004), and it could explain the differences in conception rates following fixed-time AI between these animal types.

Heifers inseminated at a fixed time after the Ovsynch protocol were more likely to experience a short luteal cycle than heifers inseminated on detection of estrus, probably because of inadequate gonadotropic stimulation of the dominant follicle and formation of a corpus luteum (CL) with a reduced life span (Schmitt et al., 1996). Growth of ovulatory follicles in the presence of reduced concentrations of progesterone $\left(\mathbf{P}_{4}\right)$ results in greater exposure to $\mathrm{LH}$, expedited maturation of follicles, increased concentrations of estradiol $\left(\mathbf{E}_{2}\right)$ during proestrus, and shorter intervals to onset of estrus (Stegner et al., 2004).

Ovulation after the first GnRH injection of the Ovsynch protocol in dairy heifers and in lactating dairy cows is dependent on the stage of the estrous cycle when the synchronization protocol is initiated, and initiation of the Ovsynch protocol during early diestrus results 
in an improved ovulation response (Vasconcelos et al., 1999; Moreira et al., 2000). The lack of ovulation following the first injection of GnRH of the Ovsynch protocol results in compromised embryo quality (Cerri et al., 2005) and reduced conception rates (Chebel et al., 2006) following Ovsynch and fixed-time AI in lactating dairy cows.

The hypotheses of the present study were that presynchronization of dairy heifers with an injection of GnRH given before initiation of the synchronization protocol would result in an increased proportion of heifers ovulating in response to the first $\mathrm{GnRH}$ injection of the synchronization protocol and that the treatment of dairy heifers with a $\mathrm{PGF}_{2 \alpha}$ injection at the time of initiation of the synchronization protocol would result in reduced $\mathrm{P}_{4}$ concentrations during the period of follicular development and expedited maturation of the ovulatory follicle. Therefore, the objectives of the present study were to evaluate the effect of presynchronization with $\mathrm{GnRH}$ on the ovulatory response of dairy heifers to the first injection of $\mathrm{GnRH}$ of the synchronization protocol and to evaluate the effect of reduced $\mathrm{P}_{4}$ concentrations on follicular development and $\mathrm{E}_{2}$ and $\mathrm{P}_{4}$ concentrations in dairy heifers.

\section{MATERIALS AND METHODS}

\section{Animals and Diet}

One hundred and seventy-three $(\mathrm{n}=173)$ Holstein heifers, between 11 and 12 mo of age and weighing approximately $360 \mathrm{~kg}$, from a commercial feedlot located in the Treasure Valley of Idaho were used in these experiments. Heifers were housed in open lots and were fed a diet as a TMR twice a day. The diet was based on corn silage, alfalfa hay, soybean meal, steam-rolled corn, whole cottonseed, brewer's grain, and a mineral and vitamin supplement and was designed to meet or exceed the nutritional requirements of Holstein heifers weighing $360 \mathrm{~kg}$ and gaining $0.8 \mathrm{~kg} / \mathrm{d}$ (NRC, 2001).

Of the 173 heifers initially enrolled in these experiments, 11 were removed because of lesions in the anus caused by frequent ultrasound examination $(n=9)$, loss of CIDR insert $(n=1)$, or for being moved to a pen with bulls before insemination $(\mathrm{n}=1)$.

\section{Treatments}

Experiment 1. To determine the optimal interval between presynchronization with $\mathrm{GnRH}$ and initiation of the synchronization protocol, 36 heifers were blocked by weight and randomly assigned to 1 of 3 presynchronization protocols. Heifers in the control group $(n=14)$ received no presynchronization treatment, heifers in the presynchronization -6 (PRES6) group $(n=11)$ re- ceived one injection of GnRH (100 $\mu$ g of gonadorelin diacetate tetrahydrate, Cystorelin, Merial Ltd., Iselin, $\mathrm{NJ}$ ) on study d -6 (study d $0=$ day of initiation of the synchronization protocol), and heifers in the presynchronization -9 (PRES9) group $(n=11)$ received one injection of GnRH on study d -9. Furthermore, heifers were blocked by presynchronization protocol and assigned to receive one injection of $\mathrm{PGF}_{2 \alpha}(25 \mathrm{mg}$ of dinoprost tromethamine sterile solution, Lutalyse, Pfizer Animal Health, Kalamazoo, MI) on study d 0 (PGF) or not (NPGF). This resulted in 6 synchronization protocols (control-NPGF $=6$, control-PGF $=8$, PRES6$\mathrm{NPGF}=5$, PRES6-PGF $=6$, PRES9-NPGF $=6$, PRES9$\mathrm{PGF}=5$ ).

On study d 0, all heifers were initiated in a synchronization protocol (Cosynch + CIDR) and received one injection of $\mathrm{GnRH}(\mathbf{G 1})$ and an intravaginal controlled internal drug releasing (CIDR) insert containing 1.38 $\mathrm{g}$ of $\mathrm{P}_{4}$ (Eazi-Breed CIDR, Pfizer Animal Health); $7 \mathrm{~d}$ later the CIDR was removed and all heifers received one injection of $\mathrm{PGF}_{2 \alpha}(\mathbf{P G})$. From study d 7 to 10 heifers were inseminated on detection of estrus and those not inseminated by $72 \mathrm{~h}$ after CIDR removal received a second injection of GnRH (G2) concomitant with AI.

Experiment 2. Heifers $(\mathrm{n}=126)$ were blocked by weight and randomly assigned to 1 of 4 synchronization protocols in a $2 \times 2$ factorial arrangement: presynchronization (PRES) or no presynchronization (NPRES) with GnRH on study d -6 (study d $0=$ day of initiation of the synchronization protocol) and treatment (PGF) or no treatment (NPGF) with an injection of $\mathrm{PGF}_{2 \alpha}$ on study $d 0$. This resulted in 4 treatments (NPRESNPGF $=32$, NPRES-PGF $=29$, PRES-NPGF $=33$, and PRES-PGF $=32$ ). Starting on study d 0, all heifers were submitted to the same Cosynch + CIDR protocol as described for experiment 1 (Figure 1).

\section{Estrus Detection and Insemination}

Heifers were observed daily in the morning for signs of behavioral estrus and for secondary signs of estrus based on tail chalk removal (Macmillan et al., 1988) by using paintsticks (All-Weather Paintstick, LA-CO Industries, Chicago, IL), and those observed in estrus were inseminated immediately. Heifers not inseminated by study d 10 received an injection of $\mathrm{GnRH}$ concomitant with AI. One technician inseminated heifers $6 \mathrm{~d}$ per week, which coincided with the majority of inseminations, and a relief technician inseminated heifers once a week.

\section{Ovarian Ultrasonography and Ovulatory Responses}

In experiment 1 , heifers in the PRES9 group had their ovaries examined by ultrasonography $(7.5 \mathrm{MHz}$ 

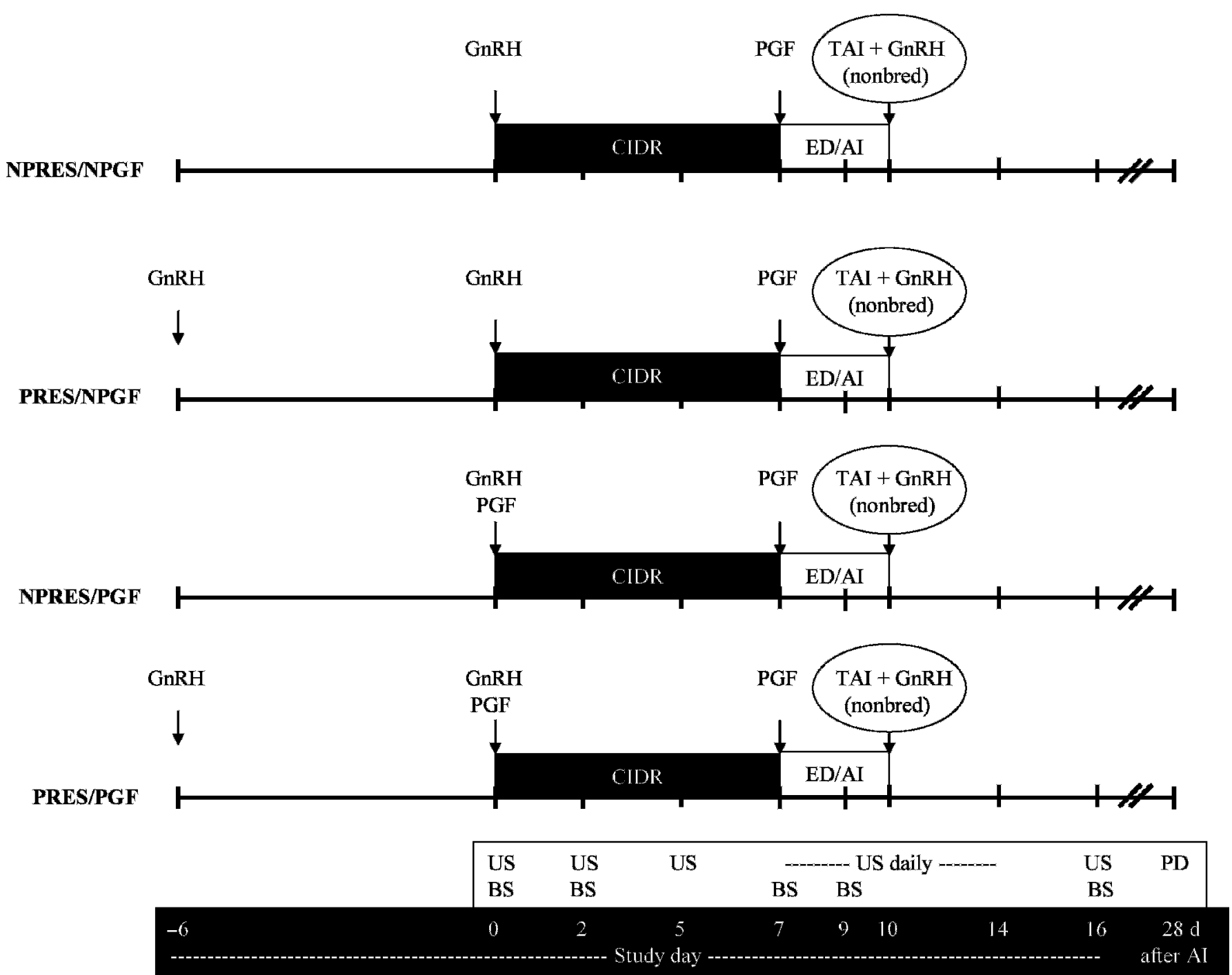

Figure 1. Diagram of activities during experiment 2. Synchronization protocols: NPRES = no presynchronization; PRES = presynchronization with one injection of GnRH on study d -6 [study d $0=$ initiation of the Cosynch + CIDR (controlled internal drug releasing insert) protocol]; $\mathrm{NPGF}=$ no treatment with $\mathrm{PGF}_{2 \alpha}$ on study d $0 ; \mathrm{PGF}=$ treatment with $\mathrm{PGF}_{2 \alpha}$ on study d 0 . All heifers were submitted to the Cosynch + CIDR protocol. TAI = timed AI; ED = estrus detection; US = ultrasonography; $\mathrm{BS}=$ blood sampling; $\mathrm{PD}=$ pregnancy diagnosis.

transrectal linear probe, Sonovet 600, Alliance Medical, Bedford Hills, NY) on study d -9 and -7 , and heifers in the control and PRES6 groups had their ovaries scanned on study d -6 . Furthermore, all heifers had their ovaries scanned with ultrasound on study $d-4$, $-2,0,2,5$, daily from study d 7 to 14 , and on study d 16 . In experiment 2 , all heifers had their ovaries scanned by ultrasound on study d $0,2,5$, daily from study $\mathrm{d} 7$ to 14 , and on study d 16 (Figure 1). Maps of the ovaries were drawn and the size and location of follicles $\geq 4$ $\mathrm{mm}$ in diameter and CL were recorded. Ovulation was characterized by the disappearance of follicles $>10 \mathrm{~mm}$ in diameter observed in the previous ultrasound examination and the formation of a CL in the ipsilateral ovary. Follicles were categorized according to diameter as class I ( $\leq 4 \mathrm{~mm})$, class II (5 to $9 \mathrm{~mm}$ ), or class III $(\geq 10 \mathrm{~mm})$.

\section{Blood Samples}

Blood samples $(10 \mathrm{~mL})$ were collected from the coccygeal vein or artery by using Vacutainer tubes (Becton Dickinson, Franklin Lakes, NJ). Samples were placed in ice and transported to the laboratory within $3 \mathrm{~h}$ of collection. Blood tubes were centrifuged at $2,000 \times g$ for $20 \mathrm{~min}$ for serum separation. Serum was harvested and frozen at $-65^{\circ} \mathrm{C}$ and later analyzed for concentrations of $\mathrm{P}_{4}$ or $\mathrm{E}_{2}$. Blood samples collected on study d $0,2,7$, 
9 , and 16 were analyzed for $\mathrm{P}_{4}$ concentrations by RIA (Kulick et al., 1999). The sensitivity of the assay was $0.006 \mathrm{ng} / \mathrm{mL}$, and the intra- and interassay coefficients of variation were 6.5 and $6.2 \%$, respectively. Samples collected on study d 9 were also analyzed for $\mathrm{E}_{2}$ concentrations by RIA (Perry et al., 2004). The sensitivity of the assay was $0.5 \mathrm{pg} / \mathrm{mL}$, and the intra- and interassay CV were 4.8 and $18.6 \%$, respectively.

\section{Pregnancy Diagnosis}

Pregnancy was diagnosed at $28 \mathrm{~d}$ after AI by scanning the uterus with ultrasound. Pregnancy was characterized by visualization of fluid and embryo. Heifers diagnosed as pregnant by ultrasonography were reexamined by palpation per rectum of the uterine content at $40 \pm 3 \mathrm{~d}$ after AI.

\section{Study Design and Statistical Analyses}

The experiments were randomized complete with blocks. In experiment 1 , heifers were blocked by weight and randomly assigned to 1 of 6 synchronization treatments in a $3 \times 2$ factorial arrangement, and in experiment 2 , heifers were blocked by weight and randomly assigned to 1 of 4 synchronization treatments in a $2 \times$ 2 factorial arrangement. Data from control and PRES6 heifers from experiment 1 were combined with data from heifers in experiment 2 . Therefore, results presented for experiment 2 contain data from 151 heifers $($ NPRES-NPGF $=38$, NPRES-PGF $=37$, PRES-NPGF $=$ 38 , and PRES-PGF $=38$ ).

The proportion of heifers that experienced ovulation in response to $\mathrm{G} 1$ in experiment 1 was analyzed by Fisher's exact test with the FREQ procedure of SAS (Statistical Analysis Software, SAS Institute Inc., Cary, NC) according to the presynchronization protocol (control vs. PRES6 vs. PRES9). Contrasts between presynchronization protocols (control vs. PRES6, control vs. PRES9, and PRES6 vs. PRES9) also were analyzed by Fisher's exact test with the FREQ procedure of SAS. The proportion of heifers ovulating in response to G1 according to the presynchronization treatment (NPRES vs. PRES) in experiment 2 was analyzed by a chisquared test with the FREQ procedure of SAS.

For analysis of all other dependent variables, the models included (unless otherwise stated) presynchronization treatment (NPRES vs. PRES), treatment with $\mathrm{PGF}_{2 \alpha}$ on study d 0 (NPGF vs. PGF), ovulation in response to G1 (ovulation vs. no ovulation), and the interactions between presynchronization and $\mathrm{PGF}_{2 \alpha}$ treatments and among presynchronization protocol, $\mathrm{PGF}_{2 \alpha}$ treatment, and ovulation in response to G1.

Concentrations of $\mathrm{P}_{4}$ from study d 0 to 9 and size of the ovulatory follicle from study d 0 to 14 or ovulation were analyzed by ANOVA with the MIXED procedure of SAS. The model also included study day and the interaction among presynchronization protocol, $\mathrm{PGF}_{2 \alpha}$ treatment, and study day. The antedependence covariance structure for repeated measures was chosen because of inconsistent intervals between data collection points. For evaluation of the size of the ovulatory follicle from study d 0 to 14, only heifers that ovulated to G1, and consequently were in the same stage of the estrous cycle, were used to better characterize the effects of $\mathrm{PGF}_{2 \alpha}$ treatment on study d 0 on follicle growth.

Continuous variables such as size of the ovulatory follicle on study d 7 and maximum size of the ovulatory follicle, concentrations of $\mathrm{E}_{2}$ on study d 9 , and $\mathrm{P}_{4}$ concentrations on study d 16 were analyzed by ANOVA with the GLM procedure of SAS. The model used to evaluate factors that affected $\mathrm{E}_{2}$ concentrations on study d 9 also included expression of estrus (estrus vs. no estrus) and size of the ovulatory follicle on study $d 7$. The model used for evaluation of factors that affected $\mathrm{P}_{4}$ concentrations on study d 16 also included size of the ovulatory follicle on study d 7 , the interval from CIDR removal to estrus, the interval from CIDR removal to ovulation, and the interactions among presynchronization and $\mathrm{PGF}_{2 \alpha}$ treatments and the intervals from CIDR removal to estrus and ovulation.

Intervals from CIDR removal to estrus or ovulation for all heifers, regardless of whether they did or did not display estrus or ovulate, were analyzed by the Cox proportional hazards regression by using the TPHREG procedure of SAS. The final logistic regression model removed variables by a backward elimination based on the Wald statistics criterion if $P>0.15$. Intervals from CIDR removal to estrus and ovulation were evaluated by survival analysis by using the product limit method of the Kaplan-Meier model with the LIFETEST procedure of SAS. Heifers that did not display estrus by $3 \mathrm{~d}$ after CIDR removal and those that did not ovulate by $5 \mathrm{~d}$ after CIDR removal were censored.

When evaluating the intervals from CIDR removal to estrus and ovulation for only heifers that displayed estrus or ovulated, the GLM procedure of SAS was used with a model that included presynchronization treatment, treatment with $\mathrm{PGF}_{2 \alpha}$, ovulation in response to $\mathrm{G} 1$, and the interactions between presynchronization and $\mathrm{PGF}_{2 \alpha}$ treatment and among presynchronization, $\mathrm{PGF}_{2 \alpha}$ treatment, and ovulation in response to G1.

Dichotomous data such as proportion of heifers displaying estrus between study $d 7$ and 10 , proportion of heifers ovulating at the end of the Cosynch + CIDR protocol, and proportion of heifers pregnant per AI (P/ AI) at 28 and $40 \mathrm{~d}$ after AI were analyzed by logistic regression by using the LOGISTIC procedure of SAS. The final logistic regression model removed variables 
by a backward elimination based on the Wald statistic criterion if $P>0.15$.

Regression analyses between the size of the ovulatory follicle on study d 7 and $\mathrm{P}_{4}$ concentrations on study $\mathrm{d}$ 16 and between the size of the ovulatory follicle on study d 7 classified in increments of $2 \mathrm{~mm}$ and the adjusted odds ratio for P/AI were evaluated by using the regression procedure of Minitab (Minitab, Minitab Inc., State College, PA) to determine the fitted line plot that best described these relationships. Orthogonal polynomials with linear, quadratic, and cubic relationships were evaluated. Treatment differences with $P \leq$ 0.05 were considered significant, and those with $0.05<$ $P<0.15$ were considered marginal.

\section{RESULTS}

\section{Experiment 1}

The proportion of heifers ovulating in response to G1 tended $(P=0.12)$ to be affected by the presynchronization protocol, and it was greater $(P=0.03)$ for heifers in the PRES6 group than in the control group (control = 14.3, PRES6 $=54.6$, PRES9 $=36.4 \%$ ). However, the proportion of heifers in the PRES9 group that ovulated in response to G1 was not different from those of the control $(P=0.22)$ and PRES6 groups $(P=0.34)$. Therefore, presynchronization with a GnRH injection $6 \mathrm{~d}$ before initiation of the synchronization protocol was used in experiment 2 .

There was a tendency $(P=0.12)$ for the presynchronization treatment to affect the size of the largest follicle at the time of G1, with control heifers having the smaller follicles (control $=11.7 \pm 0.8$, PRES6 $=13.9 \pm$ 0.9$, PRES9 $=14.0 \pm 0.9 \mathrm{~mm})$. There was no $(P=0.35)$ difference in the proportion of heifers bearing class III follicles at the time of initiating the synchronization protocol $($ control $=85.7$, PRES6 $=100.0$, PRES9 $=$ $81.8 \%)$. The proportion of heifers ovulating in response to G1, however, tended $(P=0.13)$ to be affected by follicle class $($ class II $=0.0$ vs. class III $=37.5 \%)$.

\section{Experiment 2}

The proportion of heifers ovulating in response to G1 was smaller $(P<0.01)$ for NPRES than PRES heifers (30.7 and 54.0\%, respectively). Although the size of the largest follicle at the time of G1 was not $(P=0.18)$ different between presynchronization treatments $(\mathrm{NPRES}=13.6 \pm 0.5$ vs. $\mathrm{PRES}=14.5 \pm 0.5 \mathrm{~mm})$, the proportion of heifers with class III follicles was greater $(P=0.05)$ for PRES than for NPRES heifers (96.1 and $86.7 \%$, respectively). A greater $(P<0.01)$ proportion of heifers bearing a class III follicle at initiation of the
Cosynch + CIDR protocol ovulated in response to G1 $($ class II $=0.0$ vs. class III $=46.4 \%)$.

The presynchronization protocol did not $(P=0.24)$ affect the $\mathrm{P}_{4}$ concentrations from study d 0 to 9 , but PGF heifers had decreased $(P<0.01)$ mean $\mathrm{P}_{4}$ concentrations compared with NPGF heifers. There was a tendency $(P=0.11)$ for the interaction between the presynchronization protocol and treatment with $\mathrm{PGF}_{2 \alpha}$ on study $\mathrm{d}$ 0 to affect the mean concentrations of $\mathrm{P}_{4}$ from study $\mathrm{d}$ 0 to 9 (NPRES-NPGF $=3.2 \pm 0.3$, NPRES-PGF $=2.7 \pm$ 0.3, PRES-NPGF $=4.1 \pm 0.3$, PRES-PGF $=2.6 \pm 0.3 \mathrm{ng} /$ $\mathrm{mL})$. Furthermore, there was an effect $(P<0.01)$ of the interaction between presynchronization treatment and $\mathrm{PGF}_{2 \alpha}$ treatment on a change in $\mathrm{P}_{4}$ concentration over time (Figure 2).

The size of the ovulatory follicle on study d 7 was not $(P=0.45)$ affected by the presynchronization treatment, but heifers that received an injection of $\mathrm{PGF}_{2 \alpha}$ on study d 0 had larger $(P<0.01)$ ovulatory follicles on study d 7 than heifers not receiving one (Table 1). Similarly, the maximum size of the ovulatory follicle was not $(P=$ 0.75 ) affected by the presynchronization treatment, but it was $(P<0.01)$ affected by treatment with $\mathrm{PGF}_{2 \alpha}$ on study $d 0$ (Table 1). The pattern of growth of the ovulatory follicle for heifers that ovulated in response to G1 was not $(P=0.30)$ affected by the presynchronization protocol, but it was $(P=0.04)$ affected by treatment with $\mathrm{PGF}_{2 \alpha}$ on study d 0 (Figure 3). Although the interaction between the presynchronization protocol and treatment with $\mathrm{PGF}_{2 \alpha}$ on study d 0 did not $(P=0.21)$ affect the growth pattern of the ovulatory follicle, there was a tendency $(P=0.09)$ for the interactions among the presynchronization protocol, $\mathrm{PGF}_{2 \alpha}$ treatment, and study day to affect it.

Although $\mathrm{E}_{2}$ concentrations on study d 9 were not $(P=0.76)$ affected by the presynchronization treatment, heifers treated with $\mathrm{PGF}_{2 \alpha}$ on study d 0 tended $(P=$ 0.09 ) to have decreased $\mathrm{E}_{2}$ concentrations during proestrus compared with those not treated (Table 1). Heifers that displayed estrus had $(P=0.03)$ greater $\mathrm{E}_{2}$ concentrations than those not displaying estrus $(3.8 \pm 0.5$ and $4.9 \pm 0.2 \mathrm{pg} / \mathrm{mL}$ ).

Although the presynchronization protocol did not $(P=$ 0.66) affect the rate at which heifers displayed estrus, heifers treated with $\mathrm{PGF}_{2 \alpha}$ on study d 0 displayed estrus at a faster $(P=0.02)$ rate than those not treated, and the mean $( \pm$ SEM) and median interval from CIDR removal to estrus were $2.8 \pm 0.1$ and $3.0 \mathrm{~d}$ for NPGF heifers and $2.4 \pm 0.1$ and $2.0 \mathrm{~d}$ for PGF heifers, respectively. For those heifers that displayed estrus, the presynchronization protocol did not affect $(P=0.53)$ the interval from CIDR removal to estrus, but heifers treated with $\mathrm{PGF}_{2 \alpha}$ on study d 0 had shorter $(P<0.01)$ intervals (NPRES-NPGF $=2.6 \pm 0.1$, NPRES-PGF $=$ 


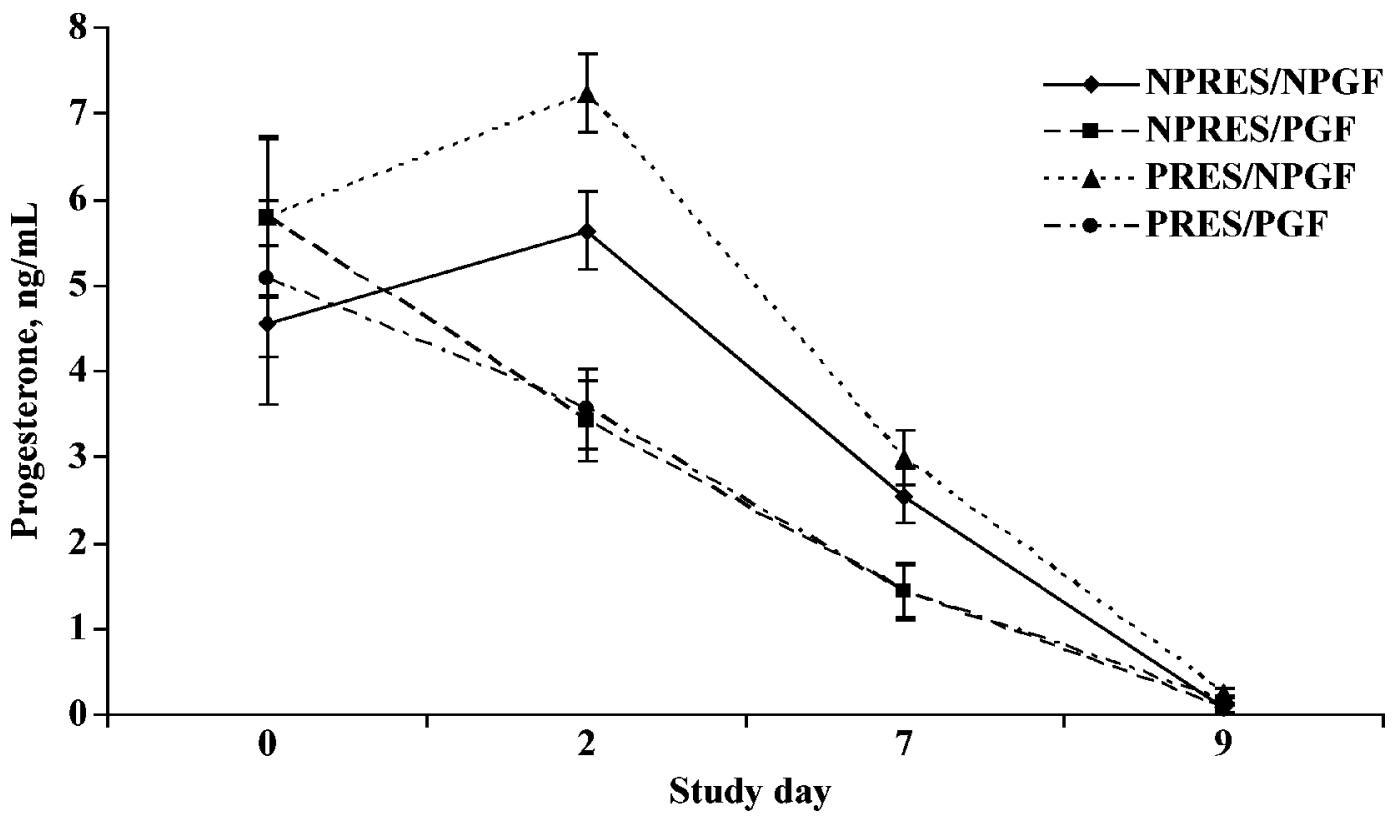

Figure 2. Effect of synchronization protocols on progesterone concentrations in experiment 2. Synchronization protocols: NPRES = no presynchronization; PRES = presynchronization with one injection of GnRH on study d -6 [study d $0=$ initiation of the Cosynch + CIDR (controlled internal drug releasing insert) protocol]; $\mathrm{NPGF}=$ no treatment with $\mathrm{PGF}_{2 \alpha}$ on study d 0; $\mathrm{PGF}=$ treatment with $\mathrm{PGF} \mathrm{F}_{2 \alpha}$ on study d 0. PRES, $P=0.24$; PGF, $P<0.01$, PRES $\times$ PGF, $P=0.11$; day, $P<0.01$; and PRES $\times$ PGF $\times$ day, $P<0.01$.

Table 1. Effect of presynchronization protocol and treatment with $\mathrm{PGF}_{2 \alpha}$ on study d 0 on follicle size and reproductive outcomes (experiment 2)

\begin{tabular}{|c|c|c|c|c|c|c|c|}
\hline \multirow[b]{2}{*}{ Item } & \multicolumn{4}{|c|}{ Synchronization protocol $^{1}$} & & & \\
\hline & NPGF & PGF & NPGF & PGF & PRES & PGF & $\mathrm{PRES} \times \mathrm{PGF}$ \\
\hline \multicolumn{8}{|l|}{ Size of ovulatory follicle, $\mathrm{mm}$} \\
\hline Study d 7 & $13.8 \pm 0.5$ & $14.9 \pm 0.5$ & $13.2 \pm 0.4$ & $14.7 \pm 0.4$ & 0.44 & $<0.01$ & 0.70 \\
\hline Before ovulation $^{2}$ & $16.9 \pm 0.4$ & $17.7 \pm 0.3$ & $16.6 \pm 0.3$ & $17.8 \pm 0.3$ & 0.75 & $<0.01$ & 0.54 \\
\hline $\mathrm{E}_{2}$ concentrations on study d $9, \mathrm{pg} / \mathrm{mL}$ & $4.7 \pm 0.5$ & $3.9 \pm 0.5$ & $4.7 \pm 0.4$ & $4.1 \pm 0.4$ & 0.76 & 0.09 & 0.89 \\
\hline $72 \mathrm{~h}$ after CIDR removal & $76.3(29 / 38)$ & $86.5(32 / 37)$ & $73.7(28 / 38)$ & $84.2(32 / 38)$ & 0.49 & 0.12 & 0.95 \\
\hline \multicolumn{8}{|l|}{ Ovulation, ${ }^{4} \%$ (n) } \\
\hline $48 \mathrm{~h}$ after CIDR removal & $5.3(2 / 38)$ & $2.7(1 / 37)$ & $2.6(1 / 38)$ & $2.6(1 / 38)$ & 0.64 & 0.66 & 0.72 \\
\hline $72 \mathrm{~h}$ after CIDR removal & $42.1(16 / 38)$ & $59.5(22 / 37)$ & $26.3(10 / 38)$ & $65.8(25 / 38)$ & 0.54 & $<0.01$ & 0.15 \\
\hline Overall & $92.1(35 / 38)$ & $94.6(35 / 37)$ & $84.5(34 / 38)$ & $94.7(36 / 38)$ & 0.34 & 0.25 & 0.55 \\
\hline $\mathrm{P}_{4}$ on study d $16, \mathrm{ng} / \mathrm{mL}$ & $1.7 \pm 0.4^{\mathrm{a}}$ & $2.7 \pm 0.4^{\mathrm{b}}$ & $2.1 \pm 0.3$ & $2.2 \pm 0.4$ & 0.82 & 0.02 & 0.07 \\
\hline \multicolumn{8}{|l|}{ Pregnancy per AI, \% (n) } \\
\hline
\end{tabular}

${ }^{\mathrm{a}, \mathrm{b}}$ Within presynchronization groups, means with different superscripts differ $(P<0.05)$.

${ }^{1}$ Synchronization protocols: NPRES = no presynchronization; PRES = presynchronization with one injection of GnRH $6 \mathrm{~d}$ before the initiation of the Cosynch + CIDR (controlled internal drug releasing insert) protocol (study d 0); NPGF = no treatment with PGF $2 \alpha$ on study $\mathrm{d} 0 ; \mathrm{PGF}=$ treatment with $\mathrm{PGF}_{2 \alpha}$ on study $\mathrm{d} 0$. All heifers received the Cosynch + CIDR protocol starting on study $\mathrm{d} 0$.

${ }^{2}$ Size of the ovulatory follicle according to the ultrasound examination before ovulation.

${ }^{3}$ Proportion of heifers inseminated upon detection of estrus from study d 7 to 10 .

${ }^{4}$ Proportion of heifers that ovulated after completion of the synchronization protocol.

${ }^{5}$ One heifer died before pregnancy diagnosis. 


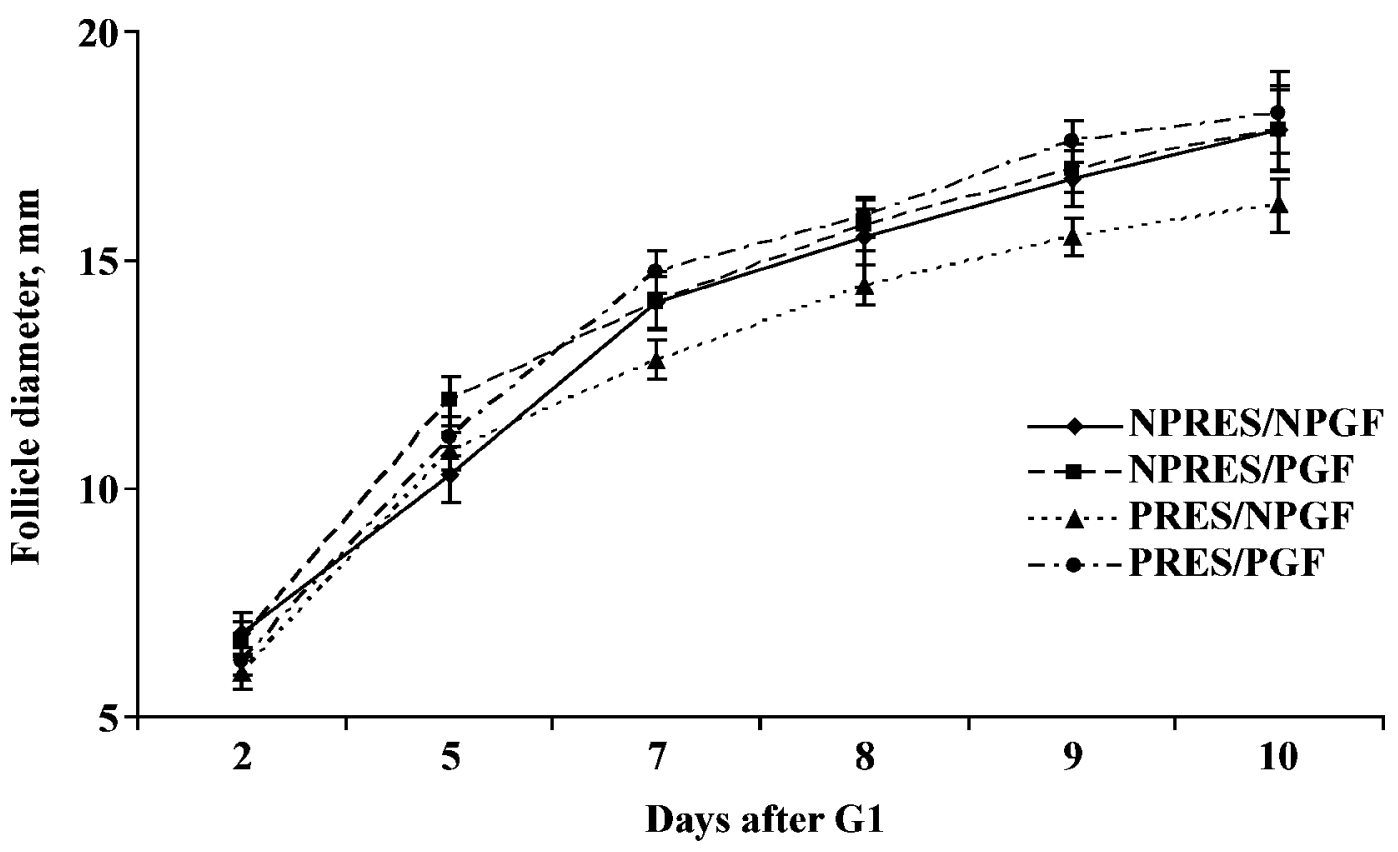

Figure 3. Effect of synchronization protocols on growth of the ovulatory follicle of heifers that ovulated in response to one injection of GnRH (G1) in experiment 2. Synchronization protocols: NPRES = no presynchronization; PRES = presynchronization with one injection of GnRH on study d -6 [study d $0=$ initiation of the Cosynch + CIDR (controlled internal drug releasing insert) protocol]; NPGF $=$ no treatment with $\mathrm{PGF}_{2 \alpha}$ on study d 0 ; PGF $=$ treatment with $\mathrm{PGF}_{2 \alpha}$ on study d 0 . PRES, $P=0.30$; PGF,$P=0.04 ; \mathrm{PRES} \times \mathrm{PGF}, P=0.21$; day, $P<0.01$; and PRES $\times$ PGF $\times$ day, $P=0.09$.

$2.4 \pm 0.1$ PRES-NPGF $=2.8 \pm 0.1$, PRES-PGF $=2.3 \pm$ $0.1 \mathrm{~d})$. Although the proportion of heifers displaying signs of estrus from study d 7 to 10 was not affected by the presynchronization protocol $(P=0.49)$, there was a tendency $(P=0.12)$ for a greater proportion of heifers treated with $\mathrm{PGF}_{2 \alpha}$ on study d 0 to display estrus (Table $1)$. This tendency was observed because a greater $(P<$ 0.01) proportion of PGF heifers displayed estrus within $48 \mathrm{~h}$ after CIDR removal compared with NPGF heifers (Table 1).

Presynchronization treatment $(P=0.75)$ did not affect the rate at which heifers ovulated, but heifers treated with $\mathrm{PGF}_{2 \alpha}$ on study d 0 had a faster $(P=0.05)$ ovulation rate than heifers that were not treated. The mean $( \pm$ SEM) and median intervals from CIDR removal to ovulation for NPGF and PGF heifers were $3.8 \pm 0.1$ and $4.0 \mathrm{~d}$, and $3.4 \pm 0.1$ and $3.0 \mathrm{~d}$, respectively. When only heifers that ovulated were used in the statistical analysis, the presynchronization protocol did not $(P=$ 0.82 ) affect the interval from CIDR removal to ovulation, but treatment of heifers with $\mathrm{PGF}_{2 \alpha}$ on study d 0 decreased $(P=0.02)$ this interval (NPRES-NPGF $=3.6$ \pm 0.1 , NPRES-PGF $=3.4 \pm 0.1$, PRES-NPGF $=3.8 \pm$ 0.1 , PRES-PGF $=3.3 \pm 0.1 \mathrm{~d}$ ). The proportion of heifers that did not ovulate after CIDR removal was not affected by either the presynchronization $(P=0.57)$ or $\mathrm{PGF}_{2 \alpha}$ treatment $(P=0.38)$. Treatment with $\mathrm{PGF}_{2 \alpha}$ on study d 0 , however, affected $(P<0.01)$ the proportion of heifers that ovulated within $72 \mathrm{~h}$ of CIDR removal (Table 1). A greater $(P<0.01)$ proportion of heifers that displayed estrus between study $\mathrm{d} 7$ and 10 ovulated after CIDR removal (100 vs. $63.3 \%)$.

Although there was no $(P=0.83)$ effect of the presynchronization protocol on $\mathrm{P}_{4}$ concentrations on study $\mathrm{d}$ 16 , heifers that received $\mathrm{PGF}_{2 \alpha}$ on study d 0 had greater $(P=0.02)$ concentrations of $\mathrm{P}_{4}$ on study d 16 (Table 1 ). The interaction between the presynchronization protocol and $\mathrm{PGF}_{2 \alpha}$ treatment on study d 0 tended $(P=0.07)$ to affect $\mathrm{P}_{4}$ concentrations on study d 16 (Table 1 ). There was no effect of the interval from CIDR removal to estrus $(P=0.30)$ or from CIDR removal to ovulation $(P=0.20)$ on $\mathrm{P}_{4}$ concentrations on study d 16. Furthermore, the interactions among presynchronization protocol, $\mathrm{PGF}_{2 \alpha}$ treatment on study d 0 , and interval to estrus $(P=0.37)$ or ovulation $(P=0.20)$ did not affect $\mathrm{P}_{4}$ concentrations on study d 16 . There was $(P<0.01)$ a positive correlation between size of the ovulatory follicle on study d 7 and $\mathrm{P}_{4}$ concentrations on study d 16 (Figure 4).

The proportion of heifers pregnant at $28 \mathrm{~d}$ after AI was not affected by the presynchronization treatment $(P=0.96)$ or by treatment with $\mathrm{PGF}_{2 \alpha}$ on study d $0(P=$ 0.97; Table 1). Ovulation in response to G1 $(P=0.55)$ and the size of the ovulatory follicle on study d 7 ( $P=$ 


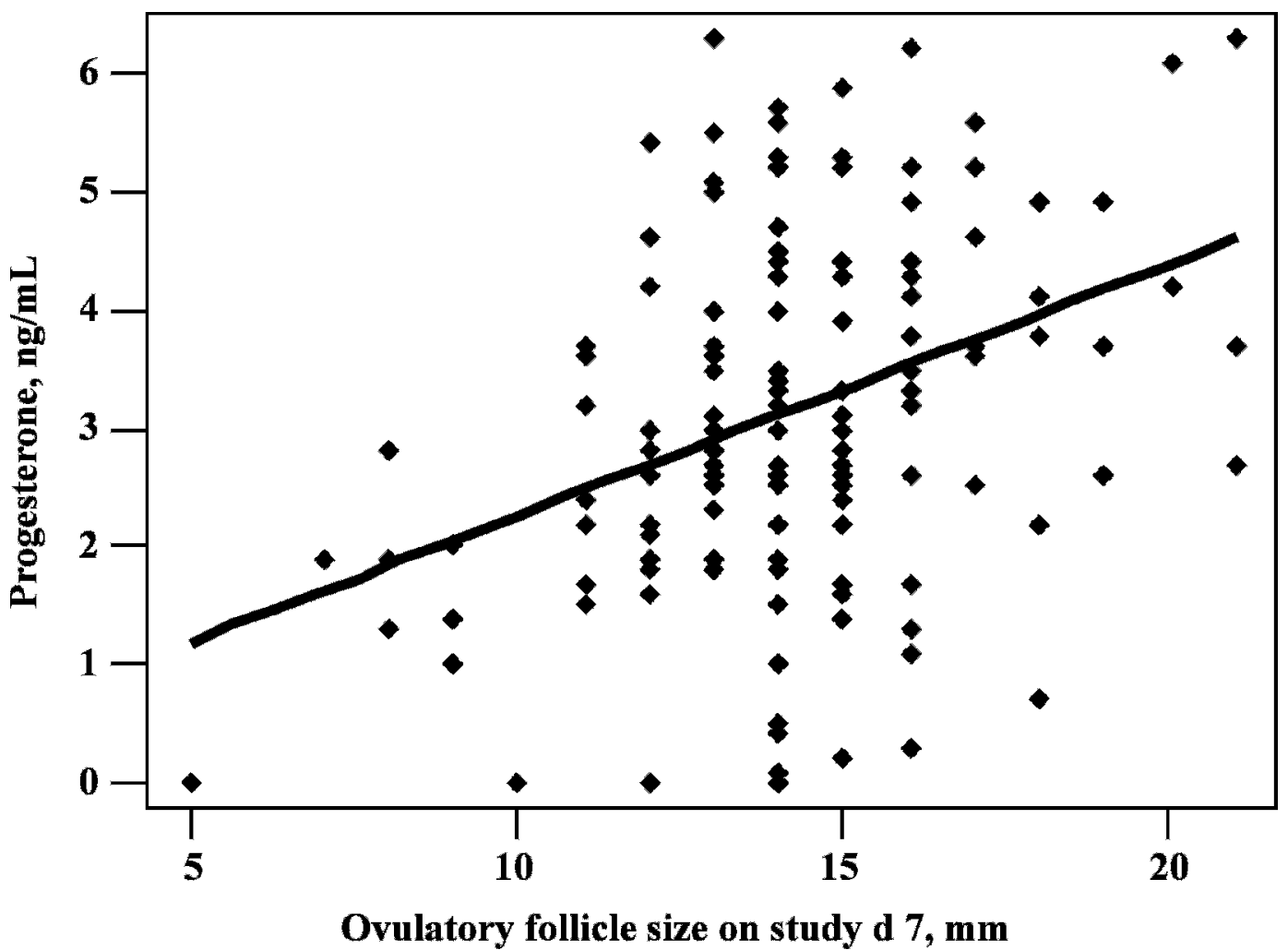

Figure 4. Correlation between size of the ovulatory follicle $(\mathrm{SOF})$ on study d 7 and progesterone $\left(\mathrm{P}_{4}\right)$ concentrations on study d $16 . \mathrm{P}_{4}=$ $0.11+0.21 \mathrm{SOF} ; \mathrm{r}^{2}=14.9 \%$. Effect of SOF on study d 7 on $\mathrm{P}_{4}$ concentrations on study d 16 according to the multivariate logistic regression model: $P<0.01$.

$0.15)$ did not affect P/AI at $28 \mathrm{~d}$ after AI. Heifers that displayed estrus had greater $(P=0.02) \mathrm{P} / \mathrm{AI}$ at $28 \mathrm{~d}$ after AI than those not displaying estrus (57.5 and 36.7\%, respectively). Similarly, heifers that ovulated at the end of the Cosynch + CIDR protocol had greater $(P=0.01)$ P/AI $28 \mathrm{~d}$ after AI (58.0 vs. $0.0 \%$, respectively).

The proportion of heifers pregnant at $40 \pm 3 \mathrm{~d}$ after AI was not affected by the presynchronization treatment $(P=0.89)$ or by treatment with $\mathrm{PGF}_{2 \alpha}$ on study d $0(P=0.55$; Table 1). Similarly, ovulation to G1 $(P=$ 0.45 ) was not correlated with $\mathrm{P} / \mathrm{AI}$ at $40 \pm 3 \mathrm{~d}$ after AI. Heifers that displayed estrus between study $\mathrm{d} 7$ and 10 were $(P=0.01)$ more likely to be pregnant $40 \pm 3 \mathrm{~d}$ after AI than those that did not display signs of estrus ( 55.0 vs. $34.5 \%$, respectively). Heifers that ovulated at the end of the Cosynch + CIDR protocol had greater $(P$ $<0.01) \mathrm{P} / \mathrm{AI}$ at $40 \pm 3 \mathrm{~d}$ after AI than those that did not ovulate ( 55.5 vs. $0.0 \%$, respectively). Interestingly, there was a tendency $(P=0.08)$ for the size of the ovulatory follicle on study d 7 to be correlated with P/ $\mathrm{AI}$ at $40 \pm 3 \mathrm{~d}$ after $\mathrm{AI}$, because heifers with follicles between 10 and $13 \mathrm{~mm}$ in diameter were more likely to be pregnant than those with follicles $\leq 9$ or $\geq 14 \mathrm{~mm}$ (Figure 5).

\section{DISCUSSION}

The recruitment of a new follicular wave by G1 of the ovulation synchronization protocols is fundamental for fertility after fixed-time AI programs. Lactating dairy cows that do not ovulate in response to G1 of the Ovsynch protocol have embryos of poorer quality (Cerri et al., 2005) and have lower conception rates (Chebel et al., 2006) compared with those cows that ovulate. A greater proportion of lactating dairy cows and dairy heifers ovulate in response to G1 when it is given during early diestrus (Vasconcelos et al., 1999; Moreira et al., 2000). In the current study (experiment 1 ), the proportion of heifers ovulating after G1 was increased by presynchronization with an injection of GnRH $6 \mathrm{~d}$ earlier, but not $9 \mathrm{~d}$ earlier. Interestingly, heifers treated with GnRH $7 \mathrm{~d}$ before the initiation of an ovulation synchronization protocol had a similar ovulation response to G1 when compared with heifers not presynchronized (Rivera et al., 2006). Treatment with GnRH causes the ovulation or luteinization of dominant follicles within $28 \mathrm{~h}$, recruitment of a new follicular wave within $48 \mathrm{~h}$, and the formation of a new CL (Thatcher et al., 1989; Macmillan and Thatcher, 1991). The interval between 


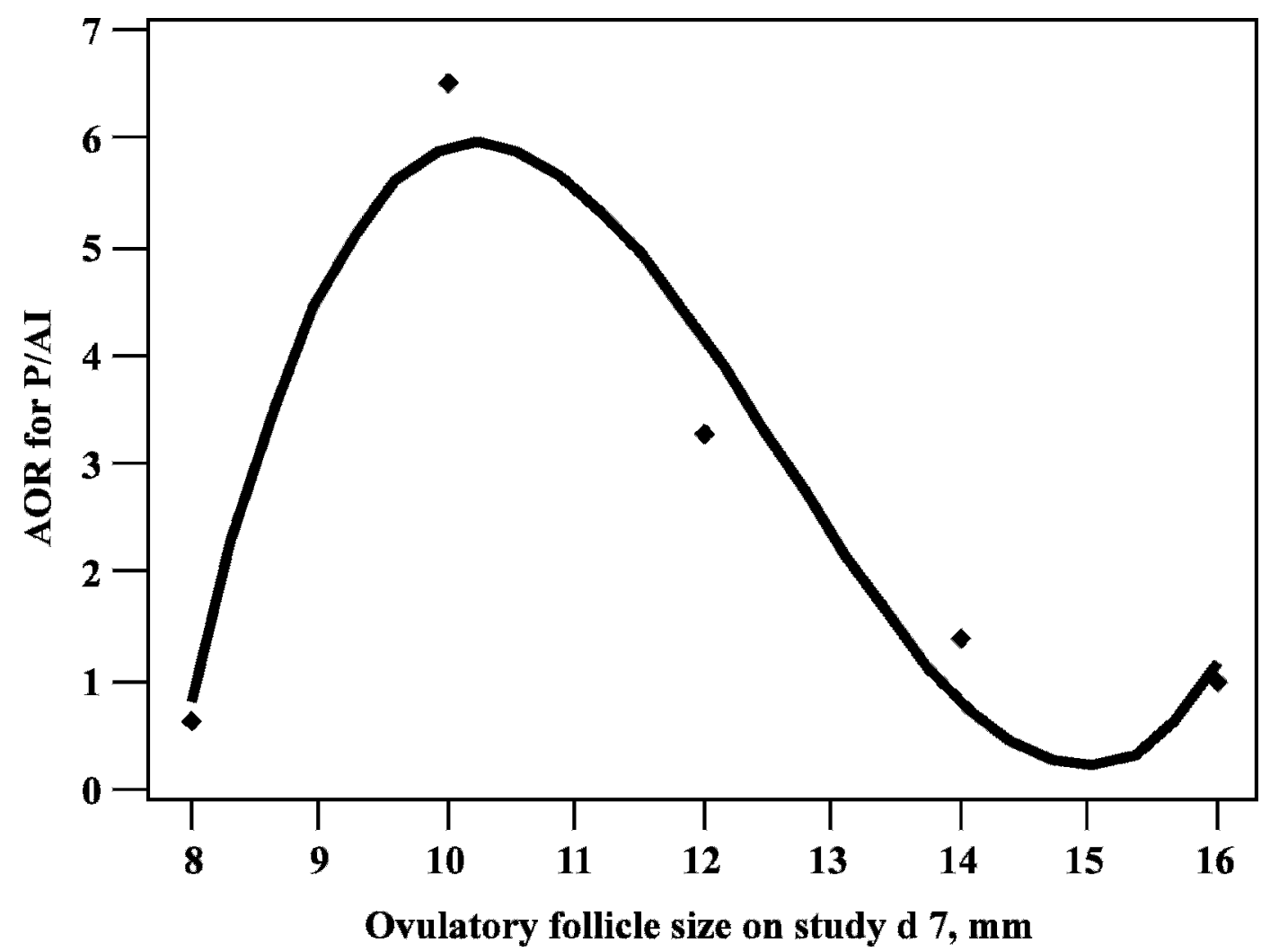

Figure 5. Correlation between the size of the ovulatory follicle (SOF) on study d 7 and the adjusted odds ratio (AOR) for proportion of heifers pregnant per AI (P/AI) $40 \mathrm{~d}$ after AI. AOR $=-194.02+50.57 \mathrm{SOF}-4.16 \mathrm{SOF}^{2}+0.11 \mathrm{SOF}^{3} ; \mathrm{r}^{2}=74.1 \%$. Effect of SOF on study d 7 on AOR for P/AI $40 \mathrm{~d}$ after AI according to the multivariate logistic regression model: $P=0.08$.

the emergence of the first and second follicular waves in dairy heifers, however, is approximately $8.9 \mathrm{~d}$ (Sartori et al., 2004). Therefore, the newly recruited dominant follicle of heifers from the PRES9 group could have been in early stages of atresia by the time of initiation of the Cosynch + CIDR protocol, which could have compromised their ovulation response. The newly recruited dominant follicles of heifers in the PRES6 group would have been in the early dominance phase, an optimum stage to ovulate in response to G1 (Vasconcelos et al., 1999; Moreira et al., 2000; Cerri et al., 2005).

The findings of experiment 1 were corroborated by experiment 2 , in which a greater proportion of heifers in the PRES groups than in the NPRES groups ovulated in response to G1. Furthermore, a greater proportion of heifers in the PRES groups had follicles of class III at the time of initiation of the Cosynch + CIDR protocol, and heifers bearing a follicle of class III were more likely to ovulate in response to G1. Sartori et al. (2001) demonstrated that ovulation in response to an $\mathrm{LH}$ injection is dependent on the size of the largest follicles, and that cows bearing follicles $\geq 10 \mathrm{~mm}$ in diameter are more likely to ovulate.
Presynchronization with GnRH did not affect the $\mathrm{P}_{4}$ concentrations during the Cosynch + CIDR protocol. Treatment with $\mathrm{PGF}_{2 \alpha}$ at the time of initiation of the Cosynch + CIDR protocol, however, resulted in decreased mean $\mathrm{P}_{4}$ concentrations from study d 0 to 9 . The interaction between the presynchronization protocol and $\mathrm{PGF}_{2 \alpha}$ treatment tended to affect the mean $\mathrm{P}_{4}$ concentrations from study d 0 to 9 , because treatment with $\mathrm{PGF}_{2 \alpha}$ on study d 0 affected only $\mathrm{P}_{4}$ concentrations in PRES heifers. This is an interesting finding because we hypothesized that $\mathrm{PGF}_{2 \alpha}$ treatment would reduce $\mathrm{P}_{4}$ concentrations regardless of the presynchronization treatment. Although it is not possible to determine clearly why heifers in the NPRES-PGF group had $\mathrm{P}_{4}$ concentrations similar to those of the NPRES-NPGF heifers, it is possible that the lack of presynchronization resulted in a greater proportion of NPRES-PGF heifers ovulating within $5 \mathrm{~d}$ of initiation of the Cosynch + CIDR protocol and treatment with $\mathrm{PGF}_{2 \alpha}$. It has been demonstrated previously that luteolysis does not occur when $\mathrm{PGF}_{2 \alpha}$ is administered on $\mathrm{d} 4$ of the estrous cycle of beef heifers (Braun et al., 1988). 
There was no effect of presynchronization with GnRH on the size of the ovulatory follicle at the time of CIDR removal (study d 7) or on the maximum diameter of ovulatory follicles, but heifers in the PGF group had larger ovulatory follicles on study $\mathrm{d} 7$ and greater maximum diameters of ovulatory follicles. Concentration of $\mathrm{P}_{4}$ is critical in determining the frequency of $\mathrm{LH}$ pulsatile release, and reduced concentrations of $\mathrm{P}_{4}$ are associated with increased pulse frequency of LH (Adams et al., 1992). Luteinizing hormone pulsatile release plays a fundamental role in the growth and function of the ovulatory follicle after deviation (Ginther et al., 2001). Therefore, the greater size of ovulatory follicles on study d 7 and greater maximum diameter of ovulatory follicles in heifers that received $\mathrm{PGF}_{2 \alpha}$ at the beginning of the synchronization protocol were likely a consequence of the decreased $\mathrm{P}_{4}$ concentrations and increased pulsatile release of $\mathrm{LH}$ during the growth of the ovulatory follicle (study d 0 to 9 ).

Estradiol concentrations on study d 9 were not correlated with the presynchronization treatment. Interestingly, heifers treated with $\mathrm{PGF}_{2 \alpha}$ on study d 0 tended to have decreased $\mathrm{E}_{2}$ concentrations compared with those not treated, despite having larger ovulatory follicles. This finding is somewhat intriguing because treatment of heifers with $\mathrm{PGF}_{2 \alpha}$ on study d 0 increased the proportion of heifers displaying estrus within 48 and $72 \mathrm{~h}$ after CIDR removal and the proportion of heifers that ovulated within $72 \mathrm{~h}$ after CIDR removal, which resulted in shorter intervals from CIDR removal to estrus and ovulation in PGF heifers compared with NPGF heifers. In beef heifers, the growth of the ovulatory follicles in the presence of decreased $\mathrm{P}_{4}$ concentrations resulted in lesser variability in the interval between $\mathrm{PGF}_{2 \alpha}$ injection and estrus and greater $\mathrm{E}_{2}$ concentrations during proestrus (Stegner et al., 2004). This could be related to high-LH pulse frequency and low-LH pulse amplitude during the development period of the dominant follicle in the presence of reduced $\mathrm{P}_{4}$ concentrations, resulting in the presence of more mature follicles at the moment of $\mathrm{PGF}_{2 \alpha}$ injection (Walters et al., 1984; Cupp et al., 1995). Luteinizing hormone stimulates the production of IGF-I, which stimulates granulosa and thecal cell proliferation, increases the number of receptors for FSH and LH, and enhances steroidogenesis by granulosa and thecal cells (Spicer and Echternkamp, 1995; Spicer, 2004). In the current study, however, such a correlation between reduced $\mathrm{P}_{4}$ concentrations during the growth of the ovulatory follicle and $\mathrm{E}_{2}$ concentrations was not observed, despite the fact that heifers that had decreased $\mathrm{P}_{4}$ concentrations had larger ovulatory follicles and shorter intervals to estrus and ovulation. Nevertheless, the fact that the majority of heifers in the PRES-PGF group displayed estrus and ovulated within 48 and $72 \mathrm{~h}$ of CIDR removal, respectively, is of interest because this tighter synchrony of ovulation could result in a successful fixed-time AI program for heifers.

Concentrations of $\mathrm{P}_{4}$ on study d 16 were similar between heifers that were or were not presynchronized. Heifers treated with $\mathrm{PGF}_{2 \alpha}$ on study d 0, however, had increased $\mathrm{P}_{4}$ concentrations on study d 16 . This difference was mainly observed because of the interaction between the presynchronization protocol and $\mathrm{PGF}_{2 \alpha}$ treatment on study d 0 , as $\mathrm{P}_{4}$ concentration on study d 16 was only different between NPRES heifers that were or were not treated with $\mathrm{PGF}_{2 \alpha}$ at the beginning of the synchronization protocol. It is not clear why no difference in $\mathrm{P}_{4}$ concentration was observed on study d 16 between PRES-NPGF and PRES-PGF heifers. We expected that the reduced concentrations of $\mathrm{P}_{4}$ during the growth of the ovulatory follicle, which were observed in NPRES-PGF and PRES-PGF heifers, would result in more mature follicles ovulating and in the formation of more functional CL and greater $\mathrm{P}_{4}$ concentrations during diestrus (Spicer and Echternkamp, 1995; Ginther et al., 2001; Spicer, 2004).

There was a positive correlation between size of the ovulatory follicle on study $\mathrm{d} 7$ and $\mathrm{P}_{4}$ concentrations on study d 16, and this correlation was not dependent on ovulation in response to G1. Lactating dairy cows that ovulated smaller and more immature follicles had reduced $\mathrm{E}_{2}$ concentrations during proestrus and reduced $\mathrm{P}_{4}$ concentrations during diestrus (Vasconcelos et al., 2001). However, when the size of the ovulatory follicles was increased by extending the interval from the injection of $\mathrm{PGF}_{2 \alpha}$ and the second injection of $\mathrm{GnRH}$ of the Ovsynch protocol, an increase in P/AI was observed without changes in concentrations of $\mathrm{P}_{4}$ (Peters and Pursley, 2003).

Although P/AI was not affected by the presynchronization protocol or $\mathrm{PGF}_{2 \alpha}$ treatment on study d 0 , it was not the aim of this study to evaluate the effects of the synchronization protocols on conception. It is likely that presynchronization of heifers with GnRH $6 \mathrm{~d}$ before the initiation of an ovulation synchronization protocol would improve fertility because of recruitment of a new follicular wave and ovulation of a fresh oocyte at the end of the synchronization protocol (Moreira et al., 2000; Cerri et al., 2005). Although it is possible that $\mathrm{PGF}_{2 \alpha}$ treatment at the initiation of the synchronization protocol could increase P/AI after timed AI by causing the ovulation of a more mature follicle and promoting a tighter synchrony of estrus and ovulation, decreased concentrations of $\mathrm{P}_{4}$ during diestrus before insemination have also been correlated with reduced fertility in lactating dairy cows (Santos et al., 2004). 
Expression of estrus affected P/AI at 28 and $40 \mathrm{~d}$ after AI. Cerri et al. (2004) observed that lactating dairy cows submitted to the Heatsynch protocol that received timed AI without expressing signs of estrus were less likely to become pregnant than those that displayed estrus. In the current study, heifers that expressed estrus had greater $\mathrm{E}_{2}$ concentrations and were more likely to ovulate after the end of the Cosynch + CIDR protocol, which may contribute to increased fertility (DeSouza and Murray, 1995; Wiltbank et al., 2002).

Interestingly, heifers with follicles between 10 and $15 \mathrm{~mm}$ in diameter at the time of CIDR removal were more likely to become pregnant than those with follicles $\leq 9$ and $\geq 16 \mathrm{~mm}$ in diameter. Perry et al. (2007) observed a similar association between the size of the ovulatory follicle and conception in beef heifers. Perry et al. (2007) have suggested that diminished competence of the oocyte that ovulates, decreased $\mathrm{P}_{4}$ concentrations during diestrus after AI, and changes in the uterine environment are related to the observed decreases in P/AI when smaller or larger follicles ovulate. Ovulation of small follicles could result in increased embryonic or fetal mortality because of impaired oocyte competence and embryo development (Santos et al., 2004; Perry et al., 2005). In the current study, there was a positive linear correlation between the size of the ovulatory follicle at CIDR removal and $\mathrm{P}_{4}$ concentrations after AI; therefore, the reduced P/AI in heifers ovulating smaller follicles could also be the result of reduced $\mathrm{P}_{4}$ concentrations during diestrus. On the other hand, Cerri et al. (2005) demonstrated that an extended period of dominance of ovulatory follicles resulted in larger follicles before ovulation and poorer quality embryos in lactating dairy cows.

\section{CONCLUSIONS}

Presynchronization of dairy heifers with an injection of GnRH $6 \mathrm{~d}$ before the initiation of the Cosynch protocol increased the proportion of heifers ovulating in response to G1 of the synchronization protocol. Furthermore, treatment of dairy heifers with $\mathrm{PGF}_{2 \alpha}$ at the time of initiation of the Cosynch protocol decreased the concentrations of $\mathrm{P}_{4}$ during the growth phase of the ovulatory follicle in presynchronized heifers and expedited the growth of the ovulatory follicles, resulting in larger ovulatory follicles at the time of CIDR removal and in reduced intervals from CIDR removal to estrus and ovulation.

\section{REFERENCES}

Adams, G. P., R. L. Matteri, J. P. Kastelic, J. C. H. Ko, and O. J. Ginther. 1992. Association between surges of follicle-stimulating hormone and the emergence of follicular waves in heifers. J. Reprod. Fertil. 94:177-188.

Braun, N. S., E. Heath, J. R. Chenault, R. D. Shanks, and J. E. Hixon. 1988. Effects of prostaglandin $\mathrm{F}_{2}$ alpha on degranulation of bovine luteal cells on days 4 and 12 of the estrous cycle. Am. J. Vet. Res. 49:516-519.

Cerri, R. L. A., H. M. Rutigliano, R. G. S. Bruno, R. C. Chebel, and J. E. P. Santos. 2005. Effect of artificial insemination (AI) protocol on fertilization and embryo quality in high-producing dairy cows. J. Dairy Sci. 88(Suppl. 1):86. (Abstr.)

Cerri, R. L. A., J. E. P. Santos, S. O. Juchem, K. N. Galvão, and R. C. Chebel. 2004. Timed artificial insemination with estradiol cypionate or insemination at estrus in high-producing dairy cows. J. Dairy Sci. 87:3704-3715.

Chebel, R. C., J. E. P. Santos, R. L. Cerri, H. M. Rutigliano, and R. G. S. Bruno. 2006. Reproduction in dairy cows following progesterone insert presynchronization and resynchronization protocols. J. Dairy Sci. 89:4205-4219.

Cupp, A. S., T. T. Stumpf, F. N. Kojima, L. A. Werth, M. W. Wolfe, M. S. Roberson, R. J. Kittok, and J. E. Kinder. 1995. Secretion of gonadotrophins change during the luteal phase of the bovine oestrous cycle in the absence of corresponding changes in progesterone or 17 $\beta$-oestradiol. Anim. Reprod. Sci. 37:109-119.

DeSouza, M. M., and M. K. Murray. 1995. An estrogen-dependent secretory protein, which shares identity with chitinases, is expressed in a temporally and regionally specific manner in the sheep oviduct at the time of fertilization and embryo development. Endocrinology 136:2485-2496.

Ginther, O. J., D. R. Bergfelt, M. A. Beg, and K. Kot. 2001. Effect of LH on circulating oestradiol and follicular fluid factor concentrations during follicle deviation in cattle. Reproduction 122:103-110.

Kulick, L. J., K. Kot, M. C. Wiltbank, and O. J. Ginther. 1999. Follicular and hormonal dynamics during the first follicular wave in heifers. Theriogenology 52:913-921.

Macmillan, K. L., D. R. Taufa, D. R. Barnes, A. M. Day, and R. Henry. 1988. Detecting estrus in synchronized heifers using tailpaint and aerosol raddle. Theriogenology 30:1099-1114.

Macmillan, K. L., and W. W. Thatcher. 1991. Effects of an agonist of gonadotropin-releasing hormone on ovarian follicles in cattle. Biol. Reprod. 45:883-889.

Moreira, F., R. L. de la Sota, T. Diaz, and W. W. Thatcher. 2000. Effect of day of the estrous cycle at the initiation of a timed artificial insemination protocol on reproductive responses in dairy heifers. J. Anim. Sci. 78:1568-1576.

Moreira, F., C. Orlandi, C. A. Risco, R. Mattos, F. Lopes, and W. W. Thatcher. 2001. Effects of presynchronization and bovine somatotropin on pregnancy rates to a timed artificial insemination protocol in lactating dairy cows. J. Dairy Sci. 84:1646-1659.

NRC. 2001. Nutrient Requirements of Dairy Cattle. 7th ed. Natl. Acad. Press, Washington, DC.

Perry, G. A., M. F. Smith, and T. W. Geary. 2004. Ability of intravaginal progesterone inserts and melengestrol acetate to induce estrous cycles in postpartum beef cows. J. Anim. Sci. 82:695-704.

Perry, G. A., M. F. Smith, M. C. Lucy, J. A. Green, T. E. Parks, M. D. MacNeil, A. J. Roberts, and T. W. Geary. 2005. Relationship between follicle size at insemination and pregnancy success. Proc. Natl. Acad. Sci. USA 102:5268-5273.

Perry, G. A., M. F. Smith, A. J. Roberts, M. D. MacNeil, and T. W. Geary. 2007. Relationship between size of the ovulatory follicle and pregnancy success in beef heifers. J. Anim. Sci. 85:684-689.

Peters, M. W., and J. R. Pursley. 2003. Timing of final GnRH of the Ovsynch protocol affects ovulatory follicle size, subsequent luteal function, and fertility in dairy cows. Theriogenology 60:11971204.

Pursley, J. R., M. R. Kosorok, and M. C. Wiltbank. 1997. Reproductive management of lactating dairy cows using synchronization of ovulation. J. Dairy Sci. 80:301-306.

Rivera, H., R. A. Sterry, and P. M. Fricke. 2006. Presynchronization with gonadotropin-releasing hormone does not improve fertility in Holstein heifers. J. Dairy Sci. 89:3810-3816.

Santos, J. E., W. W. Thatcher, R. C. Chebel, R. L. Cerri, and K. N. Galvão. 2004. The effect of embryonic death rates in cattle on 
the efficacy of estrus synchronization programs. Anim. Reprod. Sci. 82-83:513-535.

Sartori, R., P. M. Fricke, J. C. Ferreira, O. J. Ginther, and M. C. Wiltbank. 2001. Follicular deviation and acquisition of ovulatory capacity in bovine follicles. Biol. Reprod. 65:1403-1409.

Sartori, R., J. M. Haughian, R. D. Shaver, G. J. M. Rosa, and M. C. Wiltbank. 2004. Comparison of ovarian function and circulating steroids in estrous cycles of Holstein heifers and lactating cows. J. Dairy Sci. 87:905-920.

Schmitt, E. J., M. Drost, T. Diaz, C. Roomes, and W. W. Thatcher. 1996. Effect of a gonadotropin-releasing hormone agonist on follicle recruitment and pregnancy rate in cattle. J. Anim. Sci. 74:154-161.

Spicer, L. J. 2004. Proteolytic degradation of insulin-like growth factor-binding proteins by ovarian follicles: A control mechanism for selection of dominant follicles. Biol. Reprod. 70:1223-1230.

Spicer, L. J., and S. E. Echternkamp. 1995. The ovarian insulin and insulin-like growth factor system with an emphasis on domestic animals. Domest. Anim. Endocrinol. 3:223-245.

Stegner, J. E., F. N. Kojima, J. F. Bader, M. C. Lucy, M. R. Ellersieck, M. F. Smith, and D. J. Patterson. 2004. Follicular dynamics and steroid profiles in cows during and after treatment with progestinbased protocols for synchronization of estrus. J. Anim. Sci. 82:1022-1028.
Tenhagen, B. A., S. Kuchenbuch, and W. Heuwieser. 2005. Timing of ovulation and fertility of heifers after synchronization of oestrus with GnRH and prostaglandin F(2alpha). Reprod. Domest. Anim. 40:62-67.

Thatcher, W. W., K. L. Macmillan, P. J. Hansen, and M. Drost. 1989. Concepts for regulation of corpus luteum function by the conceptus and ovarian follicles to improve fertility. Theriogenology 31:149-164.

Vasconcelos, J. L., R. W. Silcox, G. J. Rosa, J. R. Pursley, and M. C. Wiltbank. 1999. Synchronization rate, size of the ovulatory follicle, and pregnancy rate after synchronization of ovulation beginning on different days of the estrous cycle in lactating dairy cows. Theriogenology 52:1067-1078.

Vasconcelos, J. L. M., R. Sartori, H. N. Oliveira, J. G. Guenther, and M. C. Wiltbank. 2001. Reduction in size of the ovulatory follicle reduces subsequent luteal size and pregnancy rate. Theriogenology 56:307-314.

Walters, D. L., D. Schams, and E. Schallenberger. 1984. Pulsatile secretion of gonadotrophins, ovarian steroids and ovarian oxytocin during the luteal phase of the oestrus cycle in the cow. J. Reprod. Fertil. 71:479-491.

Wiltbank, M. C., A. Gumen, and R. Sartori. 2002. Physiological classification of anovulatory conditions in cattle. Theriogenology $57: 21-52$. 